\title{
Penerapan Pembelajaran Kooperatif Tipe Jigsaw sebagai Wujud Penerapan Nilai-Nilai ANEKA dalam Proses Belajar Mengajar
}

\author{
${ }^{1}$ I Wayan Gede Suarjana, ${ }^{2}$ Siti Fathimah \\ Ilmu Kesehatan Masyarakat, Fakultas Ilmu Keolahragaan, Universitas negeri Manado ${ }^{1}$, Pendidikan Sosiologi, \\ Fakultas Ilmu Sosial, Universitas Negeri Manado ${ }^{2}$ \\ Kampus Unima Tondano \\ 1iwg.suarjana@unima.ac.id \\ 2 sitifathimah@unima.ac.id
}

Abstrack

The purpose of this study is to determine the basic values that must be owned and understood by Lecturers as State Civil Apparatus and to actualize the basic values of ASN through the use of the jigsaw learning method. Through this habituation activity, it is hoped that it can be a measure of success in improving public services. There are 6 supporting activities chosen to solve the selected core issues, namely making and packaging learning plans that focus on student activity. delivering learning materials using the Jigsaw cooperative learning model, compiling questions in varied forms, carrying out formative evaluations, checking student test/test results, and analyzing student test/test results. The research finding is that the actualization of ANEKA values has been successful in motivating and increasing students' understanding and activeness with innovative learning models in the Basic Occupational Health and Safety course. This increase in understanding can be seen from the results of evaluation tests in participating in learning during actualization and increasing student activity during learning time. By analyzing the results of the evaluation, it is known that student learning completeness with predicates is very good at $35 \%$, good at $50 \%$, and quite good at $15 \%$.

Keyword: basic values of the state civil apparatus, learning model jigsaw type

Abstrak

Tujuan dari penelitian ini adalah untuk mengetahui nilai-nilai dasar yang harus dimiliki dan dipahami oleh Dosen sebagai Aparatur Sipil Negara serta untuk mengaktualisasikan nilai dasar ASN melalui pemnggunaan metode pembelajaran jigsaw. Melalui kegiatan habituasi ini diharapkan dapat menjadi tolak ukur keberhasilan dalam meningkatkan pelayanan publik. Terdapat 6 kegiatan pendukung yang dipilih untuk menyelesaikan core issue yang terpilih, yaitu membuat dan mengemas perencanaan pembelajaran yang menitik beratkan pada keaktifan mahasiswa. menyampaikan materi pembelajaran dengan model pembelajaran kooperatif tipe Jigsaw, menyusun soal dengan bentuk variatif, melaksanakan evaluasi formatif, memeriksa hasil ujian/test mahasiswa, serta melaksanakan analisis hasil ujian/test mahasiswa. Temuan penelitian, bahwa aktualisasi nilai-nilai ANEKA yang dilaksanakan telah berhasil memotivasi dan meningkatkan pemahaman dan keaktifan mahasiswa degan model pembelajaran inovatif pada mata kuliah Dasar Kesehatan dan Keselamatan Kerja. Peningkatan pemahaman ini di lihat dari hasil test evaluasi dalam mengikuti pembelajaran selama aktualisasi dan meningkatkan keaktifan mahasiswa selama waktu pembelajaran berlangsung. Dengan dilakukan analisis hasil evaluasi, diketahui ketuntasan belajar mahasiswa dengan predikat amat baik $35 \%$, baik $\mathbf{5 0 \%}$, dan cukup baik $15 \%$.

Kata Kunci: nilai dasar Aparatur Sipil Negara, model pembelajaran jigsaw.

\section{PENDAHULUAN}

Peraturan baru tentang ASN tertuang dalam UU No. 5 Tahun 2014 sudah secara implisit menghendaki bahwa ASN yang umum disebut sebagai birokrat bukan sekedar merujuk kepada jenis pekerjaan tetapi merujuk kepada sebuah profesi pelayanan publik, maka dari itu sebagai ASN perlu membuat rancangan aktualisasi khususnya di pelayanan bidang Pendidikan. Dosen sebagai penyelenggara dalam kegiatan pembelajaran bukan hanya berperan membelajarkan mahasiswa tetapi berperan lebih dalam meningkatkan pemahaman dan juga keaktifan dalam kelas dalam proses belajar mengajar yang selalu dilakukan secara optimal dan maksimal.

Bukan rahasia umum lagi jika pembelajaran di perkuliahan masih sering menggunakan metode pembelajaran teacher centered yang berupa ceramah yang banyak mengandalkan pemahaman dari dosen dalam memberikan pembelajaran. Karena ceramah lebih mendominasi suatu proses pembelajaran, maka menjadi tidak aneh jika kebanyakan mahasiswa pemahaman dan keaktifan dalam perkuliahan sangat minim yang mengakibatkan mahasiswa kesulitan dalam memecahkan persoalan yang terjadi. Dosen sebagai penyelenggara dalam kegiatan pembelajaran bukan hanya berperan membelajarkan mahasiswa tetapi berperan lebih dalam memaksimalkan pemahaman dan keaktifan mahasiswa dalam merespon pembelajaran proses pembelajaran yang dilaksanakan. Metode pembelajaran yang dilakukan hampir seluruh dosen masih menerapkan pembelajaran klasikan yaitu 
ceramah. Oleh karena metode pembelajaran yang berupa ceramah yang memiliki kelemahan yaitu membuat jenuh mahasiswa yang mengakibatkan menurunnya pemahaman dan keaktifan mahasiswa berkurang karena tidak ada semangat dalam perkuliahan.

Banyak penelitian yang telah dilakukan seputar pelaksanaan model dan metode pembelajaran, mulai dengan memanfaatkan fitur yang disediakan oleh google [1] hingga model-model pembelajaran lainnya yang tak kalah menarik [2]. Dalam kondisi pembelajaran era Pandemic Covid 19 media dan metode pembelajaran memegang peranan penting bagi seorang pendidik dalam meningkatkan kualitas pembelajaranya [3]. Metode lainnya adalah metode pembelajaran kooperatif tipe jigsaw, yang merupakan salah satu model pembelajaran dengan menggunakan pengkelompokan/ tim kecil yaitu yang terdiri antara empat, enam, bahkan sampai delapan orang yang mempunyai latar belakang yang berbeda yang diberikan materi untuk dipelajari sendiri, kemudian kelompok tesebut diberi tanggung jawab untuk menjelaskan materi ke kelompok yang lain. Metode pembelajaran ini menitikberatkan pada pemahaman dan keaktifan untuk berkomunikasi menyampaikan pendapat serta menerima pendapat orang lain.

Program studi Ilmu Kesehatan Masyarakat Fakultas Ilmu Keolahragaan Universitas Negeri Manado merupakan salah satu Prodi di Fakultas Ilmu Keolahragaan UNIMA yang memiliki visi menyediakan tenaga kesehatan masyarakat yang berkarakter, inivatif, bermutu, dan berdaya saing local dan global. Perwujudan visi tersebut memerlukan kualitas sumber daya manusia yang mempuni, khususnya Aparatur Sipil Negara (ASN) di lingkungan Program Studi Ilmu Kesehatan Masyarakat FIK UNIMA dituntut harus memiliki karakter yang dilandasi dengan nilai dasar ASN yaitu ANEKA (Akuntabilitas, Nasionalisme, Etika Publik, Komitmen Mutu, Anti Korupsi). Tetapi masih banyak dosen yang belum menunjukkan kompetensi yang diperoleh melalui Pendidikan dan latihan dalam proses belajar mengajar sehingga banyak mahasiswa yang tidak memperoleh peningkatan sumber daya yang seharusnya sudah dimiliki setelah proses belajar mengajar berlangsung, atau sesudah lulus kuliah. Berdasarkan permasalahan yang diuraikan di atas, maka peneliti tertarik untuk mengkaji tentang peningkatan pemahaman dan keaktifan mahasiswa melalui pembelajaran kooperatif pada mata kuliah Dasar Kesehatan dan Keselamatan Kerja di Program Studi Ilmu Kesehatan Masyarakat Fakultas Ilmu Keolahragaan Universitas Negeri Manado yang sekaligus sebagai bagian mewujudkan penerapan nilai-nilai dasar yang harus dimiliki ASN yaitu akuntabilitas; nasionalisme; etika publik; komitmen mutu dan anti korupsiatau yang disingkat dengan nilai-nilai ANEKA.

Adapun tujuan dari penelitian ini adalah untuk mengetahui nilai-nilai dasar yang harus dimiliki dan dipahami oleh Dosen Ilmu Kesehatan Masyarakat sebagai Aparatur Sipil Negara, untuk mengaktualisasikan nilai dasar ASN. Dengan ruang lingkup dari aktualisasi ini yaitu pelaksanaan kegiatan aktualisasi yang dilaksanakan selama 30 hari kerja terhitung mulai dari tanggal 01 Maret 2020 sampai dengan 4 April 2020 di lingkungan tempat kerja yaitu Program Studi Ilmu Kesehatan Masyarakat Fakultas Ilmu Keolahragaan Universitas Negeri Manado, dengan mengaktualisasikan nilai-nilai dasar Akuntabilitas, Nasionalisme, Etika publik, Komitmen mutu, dan Anti korupsi dalam pelaksanaan jabatan sehari-hari khususnya pada Mata Kuliah Dasar Kesehatan dan Keselamatan Kerja

\section{KAJIAN PUSTAKA}

Pembelajaran kooperatif tipe jigsaw pertama kali dikembangkan dan diujicobakan oleh Elliot Aronson dan kawan-kawan di Universitas Texas, dan kemudian diadaptasi oleh Slavin di Universitas John Hopkins [4]. Sementara itu, menurut Isjoni [5] pembelajaran kooperatif tipe jigsaw salah satu tipe pembelajaran kooperatif yang mendorong siswa aktif dan saling membantu dalam menguasai materi pelajaran untuk mencapai prestasi yang maksimal. Adapun Lie [6] menyatakan bahwa metode jigsaw didesain untuk meningkatkan rasa tanggung jawab siswa terhadap pembelajarannya sendiri dan juga pembelajaran orang lain. Siswa tidak hanya mempelajari materi yang diberikan, tetapi mereka juga harus siap memberikan dan mengajarkan materi tersebut pada anggota kelompoknya yang lain. Dengan demikian, siswa saling tergantung satu dengan yang lain dan harus bekerja sama secara kooperatif untuk mempelajari materi yang ditugaskan. Para anggota dari tim yang berbeda dengan topik yang sama bertemu untuk diskusi (tim ahli) saling membantu satu sama lain tentang topik pembelajaran yang ditugaskan kepada mereka. Kemudian siswasiswa itu kembali pada tim/ kelompok 
asal untuk menjelaskan kepada anggota kelompok yang lain tentang apa yang telah mereka pelajari sebelumnya pada pertemuan tim ahli.

Abdau [7] menyampaikan ada beberapa manfaat yang dapat di peroleh ketika seorang guru menggunakan metode jigsaw kepada siswa ketika melakukan proses belajar mengajar. Manfaat metode jigsaw, antara lain: 1) Meningkatkan kemampuan diri tiap individu, 2) Saling menerima kekurangan terhadap perbedaan individu yang lebih besar, 3) Konflik antar pribadi berkurang, 4) Sikap apatis berkurang, 5) Pemahaman yang lebih mendalam, 6) Motivasi lebih besar, 7) Hasil belajar lebih tinggi, 8) Retensi atau penyimpanan lebih lama, 9) Meningkatkan kebaikan budi, kepekaan dan toleransi, 10) Cooperative learning dapat mencegah keagresifan dalam sistem kompetensi dan keterasingan dalam sistem individu tanpa mengorbankan aspek kognitif.

Penyelenggaraan Pelatihan Dasar ini bertujuan sebagai penguatan nilai-nilai dasar profesi ASN yang merupakan nilai-nilai yang harus ditanamkan oleh seluruh ASN, meliputi Akuntabilitas, Nasionalisme, Etika Publik, Komitmen Mutu dan Anti Korupsi (ANEKA), serta kedudukan dan peran ASN dalam NKRI yaitu Whole Of Government [8], Managemen ASN dan Pelayanan Publik. Berikut Nilai-nilai dasar profesi ASN, kedudukan dan peran ASN dalam NKRI yang meliputi Akuntabilitas, Nasionalisme, Etika Publik, Komitmen Mutu dan Anti Korupsi (ANEKA. Pertama adalah Akuntabilitas, merujuk pada kewajiban setiap individu, kelompok atau institusi untuk memenuhi tanggungjawab yang menjadi amanahnya. Amanah seorang PNS adalah menjamin terwujudnya nilainilai publik mampu mengambil pilihan yang tepat dan benar ketika terjadi konflik kepentingan, antara kepentingan publik dengan kepentingan sektor, kelompok, dan pribadi; mMemiliki pemahaman dan kesadaran untuk menghindari dan mencegah keterlibatan PNS dalam politik praktis; memperlakukan warga negara secara sama dan adil dalam penyelenggaraan pemerintahan dan pelayanan publik; serta menunjukan sikap dan perilaku yang konsisten dan dapat diandalkan sebagai penyelenggara pemerintahan.

Nilai yang kedua adalah nasionalisme[9], dirumuskan sebagai satu paham yang menciptakan dan mempertahankan kedaulatan sebuah negara (nation) dengan mewujudkan satu identitas sebagai ikatan bersama dalam satu kelompok. Nasionalisme Pancasila adalah pandangan atau paham kecintaan Warga Negara Indonesia terhadap bangsa dan tanah airnya yang didasarkan pada nilai-nilai Pancasila. Dengan adanya nilai- nilai Pancasila diharapkan setiap ASN memiliki rasa nasionalisme yang kuat dan lebih memikirkan kepentingan publik, bangsa dan negara dibanding kepentingan pribadi dalam menjalankan tugasnya. Nilai-nilai dasar nasionalisme yang harus diperhatikan, antara lain; religius, amanah, disiplin, non diskriminasi, saling menghormati, persamaan derajat, mencintai sesama manusia, rela berkorban, menjaga ketertiban, kerja sama, cinta tanah air, musyawarah, kekeluargaan, kepentingan bersama, hidup sederhana, tidak menggunakan hak yang bukan miliknya, kerja keras, menghargai karya orang lain, menghormati keputusan bersama, dan tenggang rasa.

Nilai yang ketiga adalah etika public, refleksi tentang baik/buruk, benar/salah perilaku, tindakan dan keputusan untuk mengarahkan kebijakan publik dalam rangka menjalankan tanggungjawab pelayanan publik. Nilai-nilai dasar etika publik antara lain: memegang teguh nilai-nilai ideologi Pancasila, setia dan mempertahankan UUD NKRI 1945, professional, tidak berpihak, membuat keputusan berdasarkan prinsip keahlian, non diskriminatif, beretika luhur, mempertanggungjawabkan tindakan dan kinerjanya kepada public, memberikan pelayanan dengan jujur, tanggap, cepat, tepat dan akurat, berdaya guna dan berhasil guna, santun dalam berkomunikasi, berkonsultasi dan bekerjasama, transparan, mengutamakan pencapaian hasil dan mendorong kinerja pegawai, mendorong kesetaraan dalam pekerjaan, dan meningkatkan efektivitas sistem pemerintahan yang demokratis sebagai perangkat sistem karir.

Keempat nilai komitmen mutu, penilaian mutu sesuatu berdasarkan pada subyektifitas seseorang, maka dari itu untuk mengukur penilaian tersebut perlu adanya standar pelayanan sehingga sebuah mutu pelayanan dapat terkontrol dengan baik. Berikut adalah nilai-nilai yang perlu diperhatikan dalam komitmen mutu antara lain: bekerja dengan berorientasi pada mutu, inovatif, selalu melakukan 
perbaikan mutu, membangun komitmen pegawai untuk jangka panjang, membangun kerjasama kolegial antarpegawai yang dilandasi kepercayaan dan kejujuran, memfokuskan kegiatan pada kepuasan pelanggan, baik internal maupun eksternal, menampilkan kinerja tanpa cacat (zerodefect) dan tanpa pemborosan (zerowaste), sejak memulai setiap pekerjaan, serta efektif dan efisien dalam bekerja. Nilai yang terakhir adalah anti korupsi, tindakan melanggar hukum dengan tujuan untuk memperkaya diri sendiri maupun golongan. Nilai-nilai yang terkandung dalam aspek anti korupsi antara lain: jujur, peduli, mandiri, disiplin, tanggungjawab, kerja keras, sederhana, berani, dan adil.

Disampin nilai-nilai aneka di atas, adapun kedudukan dan peran ASN dalam NKRI adalah pertama Whole of Government, merupakan suatu upaya dalam sistem pemerintahan yang bersatu dalam satu kesatuan untuk mencapai tujuan tertentu [8]. WoG juga memiliki pemahaman yakni suatu pendekatan penyelenggaraan pemerintah yang menyatukan upaya-upaya kolaboratif pemerintah dari keseluruhan sektor dalam ruang lingkup yang lebih luas di pemerintahan. Praktek WoG dalam pelayanan publik adalah: pelayanan yang bersifat administrative, pelayanan jasa, pelayanan barang, dan pelayanan regulative. Kedua, management ASN Visi UU ASN adalah mewujudkan ASN yang memiliki integritas profesional, melayani dan sejahtera. Misi UU ASN adalah memindahkan ASN dari comfort zone ke competitive zone. Tujuan utama UU ASN antara lain: independensi dan netralitas, kompetensi, kinerja atau produktifitas kerja, integritas, kesejahteraan, kualitas pelayanan public, pengawasan. Ketiga pelayanan public, Amanat UUD 1945 bahwa layanan untuk kepentingan publik menjadi tanggung jawab pemerintah. Pelayanan publik yang bermutu akan menciptakan kepercayaan publik kepada pemerintah. Keberhasilan institusi pemerintah memberikan layanan kepada masyarakat akan sangat bergantung pada mutu sumber daya manusia serta bagaimana potensi mereka. ASN sebagai sumber daya manusia yang dimiliki oleh pemerintah untuk melaksanakan amanah UUD 1945 memiliki fungsi sebagai pelayan publik yang bertanggung jawab untuk memberikan pelayanan prima kepada masyarakat.

Undang-undang Nomor 25 Tahun 2009 tentang Pelayanan Publik menyatakan bahwa pelayanan publik adalah kegiatan atau rangkaian kegiatan dalam rangka pemenuhan kebutuhan pelayanan sesuai dengan peraturan perundang- undangan bagi setiap warga Negara dan penduduk atas barang, jasa, dan atau pelayanan administrative yang disediakan oleh penyelenggara pelayanan publik. Tiga unsur penting dalam pelayanan publik, yaitu organisasi penyelenggara pelayanan publik, penerima layanan (pelanggan) yaitu orang, masyarakat atau organisasi yang berkepentingan, dan kepuasan yang diberikan dan atau diterima oleh penerima layanan (pelanggan). Sembilan prinsip pelayanan publik yang baik untuk mewujudkan pelayanan prima yaitu: partisipatif, transparan, responsive, non diskriminatif, mudah dan murah, efektif dan efisien, aksesibel, akuntabel, serta berkeadilan

\section{METODE PENELITIAN}

Penelitian ini dilakukan dengan menggunakan jenis penelitian tindakan kelas atau Classroom Action Research (CAR). Penelitian tindakan kelas merupakan suatu cara untuk memperbaiki dan meningkatkan profesionalisme guru, sehingga hasil belajar siswa menjadi meningkat. Proses penelitian mengacu kepada siklus penelitian tindakan kelas yang disampaikan oleh [10] yaitu dengan melakukan rangkaian kegiatan seperti perencanaan, pelaksanaan, observasi dan refleksi. Adapun instrument dalam penelitian ini adalah menggunakan pedoman observasi, lembaran tes, catatan lapangan, dan hasil karya siswa (jika ada). Dengan teknik pengumpulan data observasi partisipasi.

\section{HASIL DAN PEMBAHASAN}

Dalam rangka menyelesaikan tahap akhir laporan kegiatan aktualisasi yang dilaksanakan selama 30 hari di Program Studi Ilmu Kesehatan Masyarakat, Fakultas Ilmu Keolahragaan, Universitas Negeri Manado, beberapa kegiatan pemecahan masalah sesuai core issue terpilih "Penerapan Pembelajaran Kooperatif Tipe Jigsaw" telah dilaksanakan. Dengan mengangkat core issue tersebut diharapkan kedepannya pelayanan terhadap mahasiswa di Prodi Ilmu Kesehatan Masyarakat Fakultas 
Ilmu Keolahragaan Universitas Negeri Manado lebih optimal khususnya dalam kegiatan belajar mengajar.

Melalui kegiatan habituasi ini diharapkan dapat menjadi tolak ukur keberhasilan dalam meningkatkan pelayanan publik. Beberapa uraian yang terdiri atas penjelasan kegiatan secara umum, pemahaman nilai-nilai dasar ASN, deskripsi proses dan kualitas produk kegiatan, serta kontribusi kegiatan terhadap visi dan misi organisasi akan diuraikan dari masing-masing kegiatan di atas sebagai berikut. Terdapat 6 kegiatan pendukung yang dipilih untuk menyelesaikan core issue yang terpilih, yaitu:

1) Membuat dan mengemas perencanaan pembelajaran yang menitik beratkan pada keaktifan mahasiswa.

2) Menyampaikan materi pembelajaran dengan model pembelajaran kooperatif tipe Jigsaw.

3) Menyusun soal dengan bentuk variatif.

4) Melaksanakan evaluasi formatif.

5) Memeriksa hasil ujian/test mahasiswa.

6) Melaksanakan analisis hasil ujian/test mahasiswa.

Adapun uraian kegiatan yang dilakukan dalam penelitian ini adalah sebagai berikut.

\section{Membuat Dan Mengemas Perencanaan Pembelajaran Yang Menitik Beratkan Pada Keaktifan Mahasiswa}

Kegiatan pertama yang dilakukan sebelum melaksanakan pembelajaran di kelas adalah menyusun rencana pembelajaran semester yang baik dan menarik bagi mahasiswa, oleh karena itu rencana pembelajaran semester yang dibuat pada kegiatan perencanaan ini menitik beratkan pada keaktifan mahasiswa. Sebelum melaksanakan aktualisasi di unit kerja, terlebih dahlulu melakukan konsultasi pada atasan mengenai model pembelajaran yang digunakan dalam kelas untuk disetujui. Nilai dasar ASN yang diterapkan adalah dikategorikan masuk dalam nilai etika public (sopan santun). Selanjutnya menyiapkan rencana pembelajaran semester sebelum melaksanakan perkuliahan di kelas Mata Kuliah Dasar Kesehatan Dan Keselamatan Kerja Prodi Ilmu Kesehatan Masyarakat. Penetapan waktu kerja dan target-target peyelesaian ini penting agar RPS ini dapat diselesaikan dengan cepat dan hasil pekerjaan yang tepat dan benar. Pada tahap ini nilai dasar ASN yang diterapkan adalah etika public (cermat). Kode Etik adalah aturan-aturan yang mengatur tingkah laku dalam suatu kelompok khusus, sudut pandangnya hanya ditujukan pada hal-hal prinsip dalam bentuk ketentuan-ketentuan tertulis. Adapun Kode Etik Profesi dimaksudkan untuk mengatur tingkah laku/etika suatu kelompok khusus dalam masyarakat melalui ketentuan-ketentuan tertulis yang diharapkan dapat dipegang teguh oleh sekelompok profesional tertentu [11]. Salah satu nilai yang terkandung adalah nilai cermat, dimana penyusunan RPS dilakukan dengan sangat hati-hati. Artinya proses penyusunan RPS ini dilakukan dengan memahami dengan baik skema pengajaran yang tepat.

Merumuskan indicator dan tujuan pembelajaran, dalam hal ini peneliti merumuskan indikator dan capaian pembelajaran yang akan dicapai oleh mahasiswa selama proses pembelajaran. Hal ini berkaitan dengan profesi saya sebagai dosen yang harus mempersiapkan pembelajaran dengan baik dan terencana, menerapkan nilai dasar ASN nasionalisme (tanggung jawab); kaitan aspek tanggung jawab mempersiapkan RPS dengan konteks nasionalisme adalah mempersiapkan dokumen mengajar yang jelas dan tepat bagi seorang dosen merupakan kewajiban agar dapat menghasilkan didikan yang bermutu untuk kemajuan bangsa. Dan kemudian disusul dengan menentukan model pembelajaran, memenuhi nilai dasar ASN komitmen mutu (inovatif), menggunakan model dan metode pembelajaran yang berbeda agar pelaksanaan pembelajaran dilaksanakan dengan lebih menyenangkan dan variative dibandingkan dengan model konvensional/ceramah. Yang diikuti dengna menyusun langkah-langkah pembelajaran dengan memperhatikan pedoman yang ada.

Langkah-lagkah pembelajaran ini berdasarkan langkah-langkah pembelajaran dengan model pembelajaran kooperatif tipe jigsaw, dimana metode dapat diartikan sebagai cara yang dapat digunakan untuk melaksanakan strategi. Sanjaya [12] juga menyatakan bahwa metode merupakan 
cara yang digunakan untuk mengimplementasikan rencana yang sudah disusun dalam kegiatan nyata agar tujuan yang telah disusun tercapai secara optimal. Metode ini merupakan langkah-langkah operasional dari strategi pembelajaran yang digunakan untuk mencapai tujuan belajar. Sementara itu Achmad Sugandi [13] mendefinisikan pembelajaran sebagai cara guru memberikan kesempatan kepada si belajar untuk berfikir agar memahami apa yang dipelajari. Isjoni [5] juga mendefinisikan pembelajaran sebagai upaya guru untuk membantu siwa melakukan kegiatan belajar. Tujuan pembelajaran adalah terwujudnya efisiensi dan efektivitas kegiatan belajar yang dilakukan peserta didik. Dengan demikian, menggunnakan metode pembelajaran jigsaw diharapkan mampu untuk mewujudkan efesiensi dan efektifitas dalam proses belajar mengajar, serta memberikan gambaran jelas tentang langkah-langkah dalam kegiatan belajar tersebut.

Nilai ASN yang diambil adalah akuntabilitas (kejelasan target). Akuntabilitas adalah prinsip dasar bagi organisasi yang berlaku pada setiap level/unit organisasi sebagai suatu kewajiban jabatandalam memberikan pertanggungjawaban laporan kegiatan kepada atasannya[14], dengan adanya nilai akuntabilitas (kejelasan target) tentunya mempermudah dalam proses belajar mengajar yang sekaligus jelasnya tujuan atau target pembelajaran. Kegiatan membuat dan mengemas perencanaan pembelajaran yang menitik beratkan pada keaktifan mahasiswa ini berkaitan dengan visi organisasi, yaitu menjadi universitas yang bermutu, unggul dan diperhitungkan, dan sesuai dengan misi kedua, yaitu Meningkatkan Mutu Pendidikan Dan Pengajaran, melalui perencanaan pembelajaran semester yang disusun. Dalam RPS yang telah disusun ini merupakan bukti mutu dari pendidikan dan pengajaran yang akan dilakakan. Dalam kegiatan membuat dan mengemas perencanaan pembelajaran semester yang menitikberatkan pada keaktifan mahasiswa menghasilkan RPS yang berkualitas dan memenuhi kebutuhan mahasiswa serta mendukung penguatan nilai organisasi, yaitu Fleksibel, dilihat dari penyusunan RPS yang menitikberatkan pada kemampuan mahasiswa, dan Inovatif, dilihat dari model pembelajaran yang direncanakan lebih inovatif, dan Kompetitif, dari penyusunan RPS ini mahasiswa dapat berkompetisi untuk mencari gagasan maupun materi tentang masalah K3. Dengan melaksanakan kegiatan penyusunan RPS, bertujuan untuk mengkonsepkan atau mengarahkan mahasiswa dalam perkuliahan dan mengetahui tujuan dari pembelajaran yang ingin dicapai menjadi lebih optimal. Sehingga mahasiswa dapat memahami materi apa yang akan dibahas sebelum memulai perkuliahan dan menunjukkan keaktifan dalam kelas karena mahasiswa sudah mempelajari materi sebelum perkuliahan dimulai.

\section{Menyampaikan materi pembelajaran dengan model pembelajaran kooperatif tipe Jigsaw.}

Teknik pembelajaran jigsaw ini dikembangkan oleh Aroson et al sebagai metode Coopertaive Learning. Metode jigsaw merupakan suatu metode kooperatif yang memperhatikan skemata atau latar belakang pengalaman siswa dan membantu mengaktifkan skemata tersebut agar bahan pelajaran lebih bermakna[5]. Jigsaw learning atau pembelajaran tipe Jigsaw merupakan sebuah teknik yang dipakai secara luas yang memiliki kesamaan dengan teknik pertukaran dari kelompok ke kelompok (group-togroup exchange) dengan suatu perbedaan penting yaitu setiap peserta didik mengajarkan sesuatu. Dalam teknik ini peserta didik belajar dengan sebuah kelompoknya, dimana dalam kelompok tersebut terdapat satu orang ahli yang membahas materi tertentu [15]. Dengan demikian Kegiatan pembelajaran yang peneliti laksanakan disini maksudnya berbeda dengan metode pembelajaran yang sering dilakukan dosen-dosen yaitu metode konvensional (ceramah), tetapi lebih menitik beratkan pada keaktifan mahasiswa dalam melaksanakan proses belajar. Adapun model pembelajaran yang dimaksud adalah model pembelajaran kooperatif tipe jigsaw. Pembelajaran kooperatif adalah model pembelajaran dengan sejumlah mahasiswa sebagai anggota kelompok asal. Dalam model jigsaw, setiap mahasiswa diberi tugas mempelajari salah satu bagian materi pembelajaran tersebut. Semua mahasiswa dengan materi pembelajaran yang sama, belajar atau berdiskusi bersama dalam kelompok ahli. Dalam kelompok ahli, mahasiswa berdiskusi mencari materi dan menyusun rencana untuk mengajarkan temannya di kelompok asal. 
Adapun tahap-tahap yang dilakukan adalah menyiapkan perangkat pembelajaran sebagai bentuk perwujudan nilai akuntabilitias (konsisten), tidak mengubah ataupun membedakan dalam pelaksanaan pembelajaran terhadap rancangan yang telah dibuat. Dilanjutkan dengan melakukan apersepsi, dengan mengajak mahasiswa berdoa bersama agar pembelajaran yang didapatkan dalam proses pembelajaran menjadi berjalan lancer dan berkah hal ini merupakan penerapan nilai nasionalisme (religius). Kemudian menyampaikan tujuan pembelajaran agar mahasiswa tahu kompetensi yang harus mereka pahami dan capai. Dan melaksanakan kegiatan inti perkuliahan dengan menggunkan metode pembelajaran tipe jigsaw. Namun dalam banyak hal, kata akuntabilitas sering disamakan dengan responsibilitas atau tanggung jawab. Namun pada dasarnya, kedua konsep tersebut memiliki arti yang berbeda. Responsibilitas adalah kewajiban untuk bertanggung jawab, sedangkan akuntabilitas adalah kewajiban pertanggungjawaban yang harus dicapai [14].

Pada kegiatan ini, keterkaitan dengan mata diklat yakni Pelayanan publik, dimana kegiatan pembelajaran yang dilakukan dengan model pembelajaran kooperatif tipe jigsaw ini dapat membantu mahasiswa untuk lebih memahami dan mengaktifkan mahasiswa dalam proses belajar untuk mencapai tujuan yang diinginkan. Kegiatan menyampaikan materi pembelajaran dengan model pembelajaran kooperatif tipe jigsaw ini berkaitan dengan visi organisasi, yaitu menjadi universitas yang bermutu, unggul dan diperhitungkan, dan terkait dengan misi kedua, yaitu meningkatkan kemampuan mahasiswa yang nantinya diharapkan dapat menjadi lulusan yang berkualitas. Dalam kegiatan menyampaikan materi pembelajaran dengan model pembelajaran kooperratif tipe jigsaw ini menguatkan nilai oraganisasi yaitu, Fleksibel, Inovatif, dan Kompetitif.

\section{Menyusun Soal Dengan Bentuk Yang Variatif}

Setelah proses pembelajaran selesai dilaksanakan, kegiatan selanjutnya adalah menyusun soal test yang dimulai dengan menyiapkan literatur, literatur ini diperoleh dari materi yang sudah didapat mahasiswa pada saat berdiskusi sesuai dengan materi pembelajaran dan indicator pencapaian pembelajaran. Dengan pendekatan ini diharapkan soal-soal yang tersusun dari kisi-kisi ini dapat mengukur kemampuan pemahaman mahasiswa di kelas saat mengikuti proses pembelajaran. Kegiatan ini dimulai dengan menyiapkan literature, agar soal yang dibuat valid dan berbobot sesuai dengan bahan ajar. Pada tahap ini diharapkan nilai yang tercermin adalah nilai komitmen mutu (berorientasi pada mutu). Kemudian menyusun kisi-kisi soal, menerapkan nilai etika public (taat pada peraturan): Kisi-kisi soal diambil dari materi yang dibahas untuk membuat soal yang diamanatkan. Dan kemudian membuat soal tes dengan berpedoman pada kisi-kisi yaitu materi yang sudah dibahas, sehingga soal yang dihasilkan berkualitas dan tepat sasaran. Pada tahap ini nilai yang diterapkan adalah akuntabilitas (tanggung jawab); responsibilitas institusi dan responsibilitas perseorangan memberikan kewajiban bagi setiap individu dan lembaga, bahwa ada suatu konsekuensi dari setiap tindakan yang telah dilakukan, karena adanya tuntutan untuk bertanggungjawab atas keputusan yang telah dibuat. Responsibilitas terbagi dalam responsibilitas perorangan dan responsibilitas institusi [14]. Pada tahap ini merupakan responsibilitas atau tanggung jawa individu atas tindakan yang diperbuatnya, kewajiban seorang dosen untuk memberikan evaluasi setiap menyelesaikan satu materi pembelajaran kepada mahasiswa untuk mengetahui capaian pembelajaran. Kemudian dilanjutkan dengan pembuatan kunci jawaban, Soal yang sudah dibuat tidak disebarkan kunci jawabannya agar tidak ada mahasiswa yang dirugikan. Nilai yang diterapkan adalah nasionalisme (menjaga rahasia).

Kegiatan menyusun soal adalah salah satu bentuk tugas pendidik untuk melakukan evaluasi pembelajaran. Dalam penyusunan soal perlu adanya pelayanan yang berkeadilan dengan membuat soal menyesuaikan pada materi yang dibahas. Disamping itu, kegiatan melaksanakan penyusunan soal ujian test ini terkait dengan visi organisasi yaitu, menjadi universitas bermutu, unggul, dan diperhitungkan, dan terkait dengan misi kedua, yaitu Meningkatkan mutu mahasiswa atau lulusan, yang dimana melalui penyusunan soal ini dapat mengukur kemampuan dari mahasiswa selama proses pembelajaran. Dalam kegiatan penyusunan soal ujian test mahasiswa ini menguatkan nilai organisasi 
yaitu, Fleksibel, Inovatif, dan Kompetitif. Dengan melaksanakan kegiatan penyusunan soal test ini untuk mengukur pemahaman mahasiswa selama mengikuti proses pembelajaran serta dalam pembuatan soal ini disesuai dengan materi yang sudah dilaksanakan.

\section{Melaksanakan Evaluasi Formatif}

Evalusi formatif adalah kegiatan evaluasi yang dilakukan pada akhir pembahasan suatu topik, dan dimaksudkan untuk mengetahui sejauh manakah suatu proses pembelajaran telah berjalan sebagaimana yang direncanakan. Evaluasi formatif dilakukan pada kegiatan ini dilaksanakan setelah menyelesaikan topik/materi pembelajaran tentang Dasar kesehatan dan Keselamatan kerja "Konsep Dasar Kesehatan dan Keselamatan Kerja". Untuk mengukur ketuntasan belajar mahasiswa pada materi ini diberikan 2 tipe soal, yang pertama 10 soal pilihan ganda (objektif), dan 5 soal uraian (essay). Evaluasi dilaksanakan selama 1 jam mulai pukul 8.30 s.d 9.30 WITA yang diikuti oleh 20 mahasiswa dari 20 mahasiswa yang terdaftar di Mata Kuliah Dasar Kesehatan dan Keselamatan Kerja.

Adapun tahap kegiatan yang dilakukan adalah dimulai dengan menggandakan soal sesuai dengan jumlah mahasiswa, kegiatan ini menerapkan nilai ASN akuntabilitas (tanggung jawab); Tujuan mempersiapkan segala kelengkapan sebelum kegiatan agar pelaksanaan evaluasi berjalan dengan perencanaan yang telah dibuat. Kemudian melaksanakan apersepsi, mengajak mahasiswa terlebih dahulu berdoa bersama-sama sebelum mengerjakan soal. Kemudian mengecek kehadiran mahasiswa melalui absensi, nilai nasionalisme (religious); Tujuan mengajak mahasiswa berdoa bersama adalah mahasiswa lebih tenang dalam pengerjaan soal test. Kemudian dilanjutkan dengan membagikan lembar soal dan lembar jawaban serta mengawasi pelaksanaan test dengan menerapkan nilai dasar ASN anti korupsi (jujur); mengawasi mahasiswa ujian dengan penuh kejujuran tanpa adanya keberpihakan. Dan kemudian mengumpulkan lembar jawaban serta menutup kegiatan dengan mengucapkan salam. Dua tahap ini menerapkan nilai dasar ASN komitmen mutu (efektivitas) dan nilai nasionalisme (religius).

Melaksanakan kegiatan evaluasi formatif adalah salah satu tugas dan tanggung jawab pendidik yang sesuai dengan tujuan yakni menjadi ASN yang professional dan mempunyai etika profesi. Kegiatan melaksanakan evaluasi formatif ini terkait dengan visi organisasi yaitu menjadi universitas bermutu, unggul, dan diperhitungkan, dan berkaitan dengan misi kedua, yaitu meningkatkan mutu pendidikan dan pengajaran dari dosen dalam mencapai tujuan yang diinginkan oleh dosen agar menjadi fasilitator mahasiswa dalam memahami perkuliahan. Dalam kegiatan melaksanakan evaluasi formatif ini menguatkan nilai oraganisasi, yaitu Fleksibel, Inovatif, dan Kompetitif. Dengan melaksanakan kegiatan evaluasi formatif dalam rangka untuk mengukur tingkat pencapaian pemahaman mahasiswa terhadap materi yang telah diajarkan, oleh karena itu perlu dilaksanakannya evaluasi setiap topik pembelajaran yang mampu mengukur tingkat pemahaman mahasiswa secara optimal.

\section{Memeriksa Hasil Test Dan Mengembalikannya Kepada Mahasiswa}

Setelah melakukan evaluasi formatif, kegiatan selanjutnya adalah memeriksa hasil test ujian dari 20 orang mahasiswa dengan mengacu pada kunci jawaban yang telah dibuat sebelumnya. Kemudian lembar jawaban test setelah dilakukan pemeriksaan dikembalikan kepada mahasiswa tanggal 16 Maret 2020. Kegiatan dimulai dengan memeriksa kelengkapan lembar jawaban mahasiswa yang mengikuti ujian test, pada tahap ini menerapkan nilai dasar ASN etika public (cermat); Etika Publik merupakan refleksi tentang standar/norma yang menentukan baik/buruk, benar/salah perilaku, tindakan dan keputusan untuk mengarahkan kebijakan publik dalam rangka menjalankan tanggung jawab pelayanan public [10]. Dengan demikian dalam memeriksa kelengkapan lembar jawaban diperiksa dengan cermat dan teliti. Kemudian dilanjutkan dengan memeriksa jawaban hasil test mahasiswa dan memberikan catatan atau saran kepada mahasiswa, pada tahap ini menerapkan nilai dasar ASN anti 
korupsi (jujur) dan nasionalisme (adil); Dalam hal mengkoreksi hasil siswa tidak membeda-bedakan antara mahasiswa yang satu dengan lainnya.

Tahap selanjutnya adalah memasukkan hasil test ke daftar nilai dan kemudian mengembalikan hasil test kepada mahasiswa, pada tahap ini nilai dasar ASN yang diterapkan adalah komitmen mutu (berorientasi pada mutu): system penilaian yang digunakan sudah sesuai dngan format penilaian yang standard an sesuai dengan kompetensi yang diujikan. Dan Akuntabilitas (transparan), hal ini seperti yang dikemukakan oleh Bevaola Kusumasari dkk bahwa tujuan dari adanya transparansi adalah mendorong komunikasi yang lebih besar dan kerjasama antara kelompok internal dan eksternal; memberikan perlindungan terhadap pengaruh yang tidak seharusnya dan korupsi dalam pengambilan keputusan; meningkatkan akuntabilitas dalam keputusan-keputusan; serta meningkatkan kepercayaan dan keyakinan kepada pimpinan secara keseluruhan[14]. Dengan demikian mengembalikan lembar jawaban hasil evalusi kembali ke mahasiswa bukti transparansi ke pada mahasiswa, tidak ada yg merasa dirugikan.

Melakukan kegiatan pemeriksaan hasil test ujian mahasiswa adalah dengan melakukan penilaian test mahasiswa tugas dari seorang pendidik untuk bersikap professional. Kegiatan memeriksa hasil test mahasiswa ini terkait dengan visi organisasi yaitu, menjadi universitas bermutu, unggul, dan diperhitungkan, dan terkait dengan misi kedua, yaitu meningkatkan mutu pendidikan dan pengajaran dari dosen dalam mencapai tujuan yang diinginkan oleh dosen agar menjadi fasilitator mahasiswa dalam memahami perkuliahan. Dengan mengetahui hasil test pembelajaran mahasiswa ini dapat mengukur pencapaian belajar dan kualitas belajar mahasiswa. Dalam kegiatan memeriksa hasil test mahasiswa ini, menguatkan nilai organisasi yaitu, Fleksibel, Inovatif, dan Kompetitif. Dengan dilaksanakanya kegiatan memeriksa hasil test kemudian mengembalikan lembar hasil test mahasiswa ini bertujuan untuk memberikan informasi berupa catatan dan saran kepada mahasiswa yang nantinya akan membuat mahasiswa lebih mengetahui kemampuan dari masing-masing mahasiswa denganharapan untuk kedepannya lebih memahami materi yang diberikan dlam proses pembelajaran.

\section{Melakukan Analisis Hasil Test Ujian Mahasiswa}

Pada kegiatan ini tidak sempat dilaksanakan dikarenakan adanya surat edaran dari instansi kerja Universitas Negeri Manado tentang "Pencegahan Penyebaran Covid-19 Di Lingkungan Universitas Negeri Manado", surat edaran tersebut terbit tanggal 16 Maret 2020, surat edaran ini berlaku dari tanggal 14 s.d 31 Maret 2020, perkuliahan tidak dapat dilakukan dengan tatap muka. Pada kegiatan ini harus adanya tatap muka dengan mahasiswa untuk membahas hasil test mahasiswa yang sekiranya belum tuntas. Karena model pembelajaran ini tidak dapat dilakukkan secara online. Maka dalam kegiatan ini hanya dapat melakukan analisis hasil nilai evaluasi mahasiswa. Kegiatan dimulai dengan menginventarisasi permasalahan yang masih belum tuntas, Dari hasil analisis hasil test mahasiswa akan diperoleh nilai - nilai yang telah memenuhi standar kelulusan ataupun yang belum memenuhi standar kelulusan. Kemudian mengelompokkan mahasiswa dengan kesulitan masing-masing. Nilai yang diterapkan pada tahap ini adalah anti korupsi (peduli); sebagai seorang dosen kepedulian terhadap permasalahan mahasiswa ditunjukkan dengan melakukan bimbingan secara khusus dan mengupayakan agar semua mahasiswa dapat tuntas dalam belajar mereka. Kemudian melakukan tindak lanjut yaitu memberikan remedial kepada mahasiswa yang nilainya tidak memenuhi standar.

Bagi mahasiswa yang nilainya belum memenuhi standar kelulusan diberikan remedial berupa penjelasan ulang terkait materi-materi yang belum dipahami dan belum tuntas. Kemudian diakhir kegiatan diberikan soal uraian sejenis terkait materi yang telah diberikan untuk mengukur tingkat ketuntasan mereka, menerapkan nilai dasar ASN akuntabilitas (tanggung jawab); Memberikan bimbingan secara khusus kepada mahasiswa yang belum mencapai standar kelulusan. Dan kemudian memberikan pengayaan bagi mahasiswa, untuk peserta didik yang telah mencapai nilai standar kelulusan atau lebih diberikan pengayaan berupa tugas untuk mengerjakan soal yang memiliki tingkatan lebih tinggi berupa studi kasus, sehingga mereka menjadi lebih teratntang dan termotivasi 
untuk lebih menguasai materi yang diberikan. Adapun nilai dasara ASN yang diterapkan pada tahap ini adalah komitmen Mutu (kreatifitas): Dalam menyelesaikan permasalahan mahasiswa diupayakan dengan berbagai cara untuk melakukan bimbingan dan pengajaran seperti kegiatan remedial dan pengayaan.

Dengan kegiatan melakukan analisis hasil ujian test mahasiswa dan memberikan bimbingan secara khusus kepada mahasiswa yang belum tuntas merupakan tindakan pelayanan kepada mahasiswa agar tujuan dari pembelajaran yang direncanakan dapat terwujud. Kegiatan melaksanakan analisis hasil test mahasiswa ini terkait dengan visi organisasi yaitu, menjadi universitas bermutu, unggul, dan diperhitungkan, dan terkait dengan misi pertama, yaitu menyelenggarakan kegiatan pendidikan dalam suasana akademik yang edukatif, dengan adanya analisis hasil ujian melalui pembahasan mengenai masalah yang dihadapi mahasiswa saat melaksanakan test dilakukan dengan suasana akademik yang edukatif. Dengan memberikan pembimbingan dan pengayaan pada mahasiswa.

Dilaksanakannya kegiatan analisis hasil ujian test, mahasiswa yang nilainya belum tuntas dan belum memahami materi yang sudah diberikan akan dijelaskan kembali sehingga mahasiswa mampu memahami materi yang telah diberikan dan tujuan dari pembelajaran dapat tercapai sesuai dengan yang diharapkan. Kendala dalam pelaksanaan aktualisasi kegiatan ke-6 adalah adanya surat edaran dari universitas dalam pencegahan penyebaran Covid-19 di lingkungan Universitas. Untuk kegiatan ke-6 ini tidak dapat dilakukan secara online karena konsep dalam kegiatan ini adalah menjelaskan dan mengelompokkan mahasiswa sesuai dengan permasalahan yang belum tuntas yang mengakibatkan nilai dari mahasiswa tidak memenuhi standar.

Gambar. 1. Presentase Ketuntasan Belajar Masiswa IKM Mata Kuliah K3

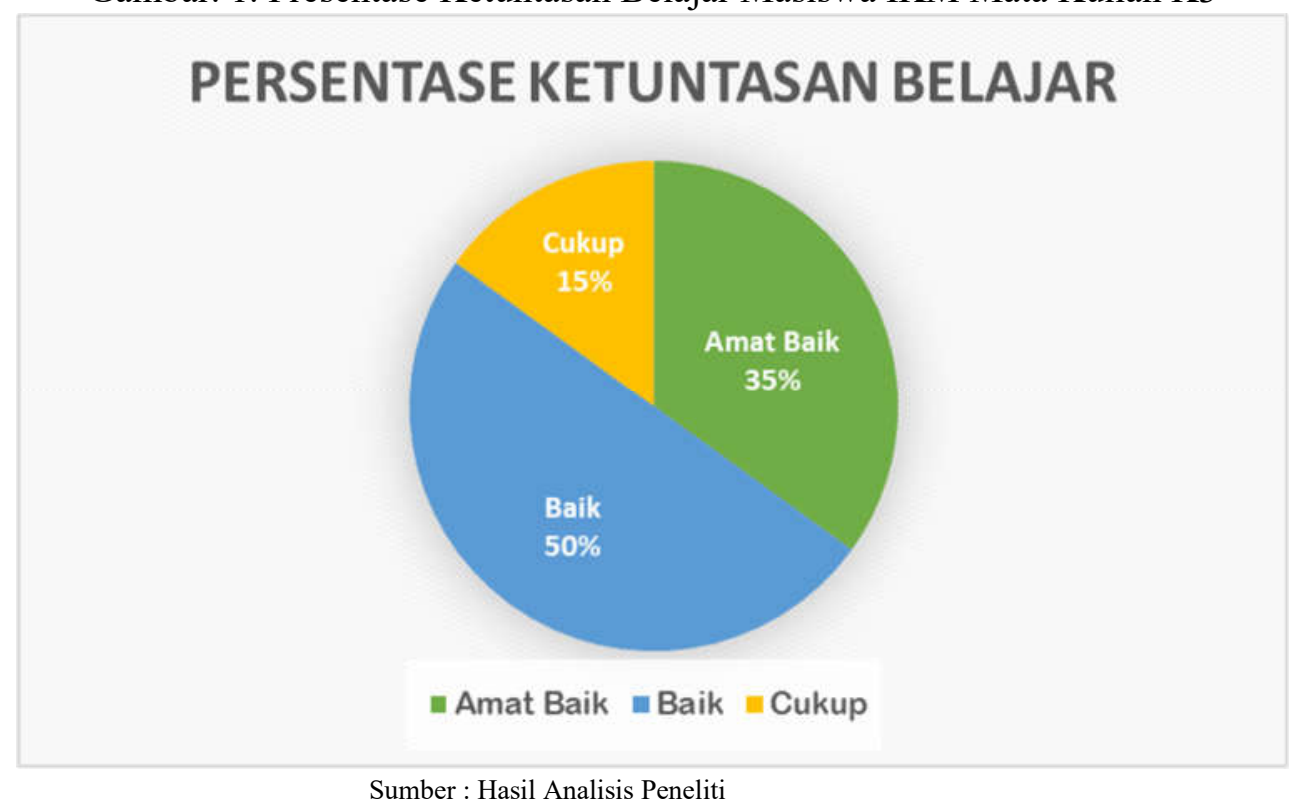

\section{KESIMPULAN DAN SARAN}

Seluruh pelaksanaan kegiatan aktualisasi selama 30 hari kerja sejak tanggal 29 Februari sampai dengan 4 April 2020 yang dilaksanakan di Prodi Ilmu Kesehatan Masyarakat Fakultas Ilmu Keolahragaan Universitas Negeri Manado terlaksana dengan baik dan lancer. Setiap tahapan dilaksanakan dengan baik dan sesuai dengan rencana serta tujuan utama untuk memberikan pembelajaran dan bimbingan yang terbaik kepada seluruh mahasiswa. Aktualisasi nilai-nilai ANEKA yang dilaksanakan telah berhasil memotivasi dan meningkatkan pemahaman dan keaktifan mahasiswa degan model pembelajaran inovatif pada mata kuliah Dasar Kesehatan dan Keselamatan Kerja. Peningkatan pemahaman ini di lihat dari hasil test evaluasi dalam mengikuti pembelajaran selama 
aktualisasi dan meningkatkan keaktifan mahasiswa selama waktu pembelajaran berlangsung melalui diskusi kelompok ahli dan kelompok asal yang dapat meningkatkan pemahaman peserta didik terhadap materi. Metode Jigsaw ini melibatkan peserta didik untuk berinteraksi satu sama lain melalui kelompok ahli dan kelompok asal sehingga peserta didik terbiasa untuk aktif berkomunikasi, baik memberikan pertanyaan maupun memberikan pernyataan atau tanggapan dari materi yang diperolehnya.

Adapun hasil analisis evaluasi, diketahui ketuntasan belajar mahasiswa dengan predikat amat baik $35 \%$, baik $50 \%$, dan cukup baik $15 \%$. Kegiatan aktualisasi ini berjalan dengan baik dan sukses, tidak lepas dari kesadaran dan kerja sama seluruh mahasiswa serta bantuan seluruh keluarga besar Prodi Ilmu Kesehatan Masyarakat Fakultas Ilmu Keolahragaan Universitas Negeri Manado. Disamping itu perencanaan yang baik dan kesungguhan dalam mengaktualisasikan nilai-nilai ANEKA dalam menjalankan tugas sehari-hari di kampus harus menjadi komitmen bersama seluruh dosen dan pegawai sehingga dapat memberikan pelayanan yang baik dan berkualitas bagi seluruh mahasiswa. Dengan terlaksananya seluruh kegiatan aktualisasi ini dengan baik dan lancar serta tercapainya tujuan pembelajaran yang diharapkan, maka dapat direkomendasikan agar kegiatan ini terus dilakukan secara kesinambungan oleh semua dosen demi terciptanya dosen yang professional, sehingga dapat memberikan pembelajaran dan bimbingan yang terbaik bagi seluruh mahasiswa. Karena keterbatasan waktu pelaksanaan aktualisasi dan banyak kendala lain yang mengakibatkan aktualisasi ini tidak dapat dimaksimalkan secara penuh, maka rencana tindak lanjut yang akan dilakukan adalah menerapkan model pembelajaran ini ke seluruh mahasiswa di Program Studi Ilmu Kesehatan Masyarakat.

\section{DAFTAR PUSTAKA}

[1] S. Fathimah, S. Sidik, and R. Rahman, "Google Docs Sebagai Solusi Pengerjaan Tugas Kelompok Dalam Pembelajaran Daring Di Tengah Pandemi Covid 19," Ilmu Sos. dan Pendidik., vol. 4, no. 3, pp. 272-279, 2020.

[2] M. E. Wantah, S. Fathimah, F. I. Pendidikan, and U. N. Manado, "Permainan Playdoh dalam Peningkatan Kreativitas Anak," vol. 4, no. 4, 2020.

[3] Tetep \& Alni, D (2021). Fun Pattern Based Learning Approach fos Social Studies Learning during The Covid 19 Pandemic. Al-Ishlah : Journal Pendidikan. ISSN: 2087$9490 \quad$ (Printed); 2597-940X (Online). http://www.journal.staihubbulwathan.id/index.php/alishlah. Doi 10.35445/alishlah.v13i3.1025

[4] R. Arends, Learning To Teachbelajar Untuk Mengajar, Edisi ketu. Jakarta: Pustaka Pelajar, 2008.

[5] Isjoni, Pembelajaran Kooperatif Meningkatkan Kecerdasan Komunikasi Antar Peserta Didik. Jakarta: Pustaka Pelajar, 2009.

[6] A. Lie, Cooperative Learning : Mempraktikkan Cooperative Learning di Ruang Ruang Kelas. Jakarta: Grasindo, 2004.

[7] I. Abdau, Implementasi Penggunaan Metode Jigsaw Learning dalam Pembelajaran PAI di SMA Darus Syahid Sampang Madura. Surabaya: UIN Sunan Ampel Surabaya, 2016.

[8] Y. Suwarno and T. A. Sejati, Modul Pelatihan Dasar Calon PNS Whole of Government. Jakarta: Lembaga Administrasi Negara, 2016.

[9] Y. Latief, A. Suryanto, and A. A. Muslim, Nasionalisme; Modul Pendidikan dan Pelatihan Prajabatan Golongan III. Jakarta: Lembaga Administrasi Negara, 2015.

[10] W. Igak, Penelitian Tindakan Kelas. Jakarta: Universitas Terbuka, 2007.

[11] W. Kumorotomo, N. R. D. Wirapradja, and A. Imbaruddin, Etika Publik: Modul Pendidikan dan Pelatihan Prajabatan Golongan III. Jakarta: Lembaga Administrasi Negara, 2015. 
[12] W. Sanjaya, Kurikulum dan Pembelajaran, Cet. II. Jakarta: Kencana, 2009.

[13] A. Sugandi and Haryanto, Teori Pembelajaran. Semarang: Unnes Pers., 2004.

[14] B. Kusumasari, S. Dwiputrianti, and E. L. Allo, Akuntabilitas Modul pendidikan dan Pelatihan Prajabatan Golongan III. Jakarta: Lembaga Administrasi Negara, 2015.

[15] M. L. Silberman, Active Learning 101 Stategi Pembelajarn Aktif. Yogyakarta: Yappendis, 2002. 